\title{
Resistensi Masyarakat Terhadap Rencana Pembangunan PLTP (Pembangkit Listrik Tenaga Panas Bumi) di Gunung Talang Kabupaten Solok
}

\author{
Eril Sastra Hadi ${ }^{1}$ Eka Vidya Putra ${ }^{2}$ \\ 1,2Universitas Negeri Padang \\ Email: erilsastrah@gmail.com,
}

\begin{abstract}
Abstrak
Penelitian ini dilatar belakangi oleh penolakan masyarakat terhadap rencana pembangunan proyek geothermal atau PLTP di Gunung Talang Kabupaten Solok, Sumatera Barat. Tujuan penelitian ini untuk mengetahui alasan masyarakat menolak rencana pembangunan proyek PLTP di Gunung Talang.Teori yang digunakan adalah teori Difusi Inovasi dari Everett M. Rogers.Metode penelitian yang digunakan adalah kualitatif dengan tipe studi kasus jenis intrinsik dan pemilihan informan dengan teknik purposive sampling sebanyak 13 orang informan. Dalam pengumpulan data dilakukan dengan cara observasi, wawancara dan dokumentasi serta menggunakan triangulasi pengamat dari Neuman. Teknik analisis data yang digunakan adalah teknik analisis data dari Miles dan Huberman (reduksi data, display data, dan penarikan kesimpulan). Hasil penelitian ini menunjukkan bahwa penolakan masyarakat disebabkan karena tiga alasan. Alasan tersebut, yaitu: (1) faktor pengetahuan, (2) faktor ekonomi, dan (3) faktor sosial budaya.

Kata Kunci: Resistensi, Masyarakat, PLTP (Pembangkit Listrik Tenaga Panas Bumi)

Abstract
This research was motivated by the public's rejection of the planned construction of a geothermal project or PLTP at Gunung Talang, Solok Regency, West Sumatra.. The purpose of this study was to find out the reasons for the community rejecting the PLTP project development plan at Gunung Talang. The theory used is the theory of innovation diffusion from Everett M. Rogers. The research method used is qualitative type intrinsic case study and informant selection with a purposive sampling technique of 13 informants. In data collection carried out by observation, interviews and documentation and using observer triangulation from Neuman. The data analysis technique used is data analysis techniques from Miles and Huberman (data reduction, data display, and conclusion drawing). The results of this study indicate that community rejection is caused for three reasons. The reasons are:(1) knowledge factors, (2) economic factors, and (3) socio-cultural factor.
\end{abstract}

Keywords: Resistance, Society, PLTP (Geothermal Power Plant)

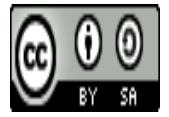

Received: July 31, 2019

Revised: August 2, 2019

Available Online: August 3, 2019 


\section{Pendahuluan}

Panas bumi atau geothermal merupakan salah satu energi baru terbarukan yang terbentuk di dalam kerak bumi (Afriandi \& Hantoro, 2018). Dalam Undang-Undang Republik Indonesia Nomor 21 Tahun 2014 tentang Panas Bumi menyatakan bahwa Panas Bumi merupakan sumber daya alam terbarukan dan merupakan kekayaan alam yang berada di dalam wilayah Negara Kesatuan Republik Indonesia sebagai karunia Tuhan Yang Maha Esa yang mempunyai peranan penting untuk menunjang pembangunan nasional yang berkelanjutan guna mewujudkan kesejahteraan rakyat (Undang-Undang Republik Indonesia Nomor 21 Tahun 2014 Tentang Panas Bumi, 2014). Geothermal mengandalkan uap air atau air panas yang ada di dalam perut bumi untuk menghasilkan tenaga listrik dan termasuk ke dalam sumber energi yang ramah lingkungan.

Pengembangan Pembangkit Listrik Panas Bumi (PLTP) merupakan satu langkah penting guna meningkatkan peran sumber energi terbarukan dalam memenuhi kebutuhan listrik di Indonesia. Pemanfaatan energi panas bumi menjadi sebuah alternatif dan suatu inovasi sebagai pengganti minyak bumi dan batu bara yang biaya produksinya lebih mahal.

Pembangunan geothermal atau Pembangkit Listrik Panas Bumi (PLTP) sudah banyak dioperasikan di Indonesia, seperti PLTP Kamojang di Kabupaten Garut, PLTP Lahendong di Sulawesi Utara, PLTP Sibayak di Gunung Sinabung Sumatera Utara, PLTP Ubelulu di Lampung, PLTP Gunung Salak, PLTP Darajat dan PLTP Wayang Windu di Jawa Barat.

Rencana pembangunan Pembangkit Listrik Panas Bumi atau proyek geothermal juga akan dilakukan di Gunung Talang Kabupaten Solok, Sumatera Barat. Pembangunan PLTP di Gunung Talang akan dikelola dan dikembangkan oleh PT. Hitay Daya Energi dan PT. Dyfco Energi yang dimenangkan dari PT. Pertamina dalam lelang Wilayah Kerja Panas Bumi (WKP) Gunung Talang. PT. Hitay Daya Energi sudah mendapatkan izin pembangunan panas bumi seluas 27.000 hektare di kawasan Gunung Talang dalam jangka waktu 37 tahun.

Dalam perencanaan tersebut, pembangunan proyek geothermal atau PLTP di Gunung Talang mendapatkan penolakan dari masyarakat setempat. Penolakan tersebut berawal padapertengahan tahun 2016, dimana pemerintahan nagari mengumumkan bahwa ada proyek pengembangan panas bumi di wilayah Gunung Talang. Hal ini membuat masyarakat terkejut akan pemberitahuan yang secara tiba-tiba diumumkan tersebut. Ditambah dengan kecurigaan masyarakat dengan adanya kedatangan beberapa orang petugas dari pihat PT. Hitay Daya Energi yang datang ke pintu masuk proyek geothermal di Nagari Batu Bajanjang dan melakukan aktivitas eksplorasi dengan mematok lubang pengeboran sumur panas bumi di beberapa titik sekitar Gunung Talang.

Penolakan yang dilakukan oleh masyarakat berupa melakukan unjuk rasa atau demonstrasi di depan Kantor Bupati Kabupaten Solok pada tanggal 13 september 2017, menghadang dan menghalangi pihak PT. Hitay Daya Energi dan aparat yang datang ke lokasi pengeboran sumur panas bumi yang terjadi pada tanggal 21 maret 2018, membuat spanduk dan baliho, mendirikan camp-camp di area pintu masuk proyek geothermal yang berada di Jorong Lurah Nagari Batu Bajanjang Kecamatan Lembang Jaya,dan membuat pernyataan penolakan di media sosial. Masyarakat setempat juga membentuk sebuah aliansi yang mereka namakan Aliansi Masyarakat Salingka (sekitar) Gunung Talang yang merupakan perkumpulan masyarakat yang menolak pembangunan proyek PLTP tersebut. Aliansi ini terdiri dari tiga kecamatan, yaitu Kecamatan Danau Kembar, Kecamatan Lembang Jaya dan Kecamatan Gunung Talang.Pemerintahan nagari sangat menyanyangkan penolakan yang dilakukan masyarakat, karena akibat dari penolakan tersebut membuat beberapa orang masyarakat menjadi DPO (Daftar Pencarian Orang) yang diduga sebagai provokator dalam aksi-aksi yang telah dilakukan.

Jurnal Perspektif: Jurnal Kajian Sosiologi dan Pendidikan Vol. 2, No. 3, Th. 2019 ISSN. 2622-174 
Mengikuti defenisi "bencana pembangunan" yang di tawarkan Oliver-Smith, bencana bukanlah semata peristiwa, tetapi juga proses yang dapat diurai dengan menelusuri rantai agenda politik yang melingkupinya sehingga dapat memunculkan kesadaran akan pentingnya tindakan preventif terhadap kemunculan suatu bencana(Novenanto \& Novenanto, 2016). Dalam hal ini, penolakan yang dilakukan oleh masyarakat terhadap suatu pembangunan merupakan upaya untuk menanggulangi bencana yang diakibat oleh pembangunan itu sendiri.

Dalam pola eskalasi konflik yang terjadi dalam kasus pembangunan Waduk Jatigede Kabupaten Sumedang, yaitu (1) kegelisahan,(2) keluhan,(3) laporan, (4) penghalangan,(5) demonstrasi, (6) demonstrasi disertai ancaman dan/atau perusakan, (7) demonstrasi disertai korban jiwa \& materil(Rachmawan, 2016). Jika kasus pembangunan Waduk Jatigede dijadikan sebagai alat ukur untuk mengukur resistensi dan penolakan masyarakat terhadap rencana pembangunan geothermal di Gunung Talang, maka resistensi dan penolakan tersebutsudah sampai ke tahap yang keenam, yaitu demonstrasi dan/atau perusakan.

Berdasarkan permasalahan di atas, terlihat sikap resistensi masyarakat terhadap pembangunan geothermal di bahu Gunung Talang yang merupakan sebuah inovasi baru dalam menghasilkan dan memenuhi kebutuhan listrik di Indonesia. Permasalahan inilah yang mendorong dan membuat peneliti tertarik untuk melakukan penelitian lebih lanjut mengenai penolakan masyarakat terhadap rencana pembangunan PLTP tersebut.

Penelitian yang relevan dengan penelitian ini adalah penelitian yang dilakukan oleh Hamzah Kurniawan yang berjudul Persistensi dan Resistensi Masyarakat terhadap Eksisitensi Pertambangan Emas di Desa Bonto Katute Kabupaten Sinjai. Hasil penelitiannya menunjukkan bahwa setelah ditetapkan izin eksplorasi penambangan secara umum masyarakat Desa Bonto Katute terbagi menjadi dua kelompok yakni masyarakat yang menerima kemudian mendukung (persistensi) dan masyarakat yang menolak (resistensi) terhadap eksplorasi penambangan emas (Kurniawan, 2013). Perbedaan penelitian adalah dalam penelitian Hamzah Kurniawan meneliti tentang persistensi dan resistensi terhadap perizinan ekplorasi penambangan emas di Desa Bonto Katute, sedangkan pada penelitian peneliti hanya meneliti tentang penolakan yang dilakukan oleh Aliansi Masyarakat Salingka Gunung Talang terhadap rencana pembangunan proyek PLTP di kawasan Gunung Talang yang tidak termasuk dalam kategori pertambangan.

\section{Metode Penelitian}

Jenis penelitian yang dipilih merupakan pendekatan kualitatif. Kualitatif merupakan metode-metode untuk mengeksplorasi dan memahami makna yang oleh sejumlah individu atau sekelompok orang dianggap berasal dari masalah sosial atau kemanusiaan (W.Creswell, 2016). Peneliti memilih metode kualitatif dalam penelitian ini karena hanya terdiri dari satu variabel saja peneliti akan dapat mengungkapkan permasalahan dan melakukan pemeriksaan terperinci mengenai kasus yang muncul secara alamiah dalam kehidupan sosial yang lebih mendalam mengenai alasan yang menjadi latar belakang resistensi Masyarakat Salingka Gunung Talang terhadap rencana pembangunan proyek PLTP di Gunung Talang. Tipe penelitian yang digunakan dalam penelitian ini adalah tipe studi kasus jenis intrinsik. Studi kasus merupakan rancangan penelitian yang ditemukan di banyak bidang, khususnya evaluasi, dimana peneliti mengembangkan analisis mendalam atas suatu kasus, seringkali program, peristiwa, aktivitas, proses, atau satu individu atau lebih (W.Creswell, 2016). Peneliti menggunakan tipe studi kasus intrinsik karena peneliti akan melakukan penelitian berdasarkan pada pedoman wawancara. Kemudian membuat pertanyaan-pertanyaan kecil berdasarkan informasi yang disampaikan informan sampai peneliti menemukan informasi yang lebih jelas mengenai topik penelitian ini. 
Lokasi penelitian ini dilakukan di Nagari Batu Bajanjang, Nagari Salayo Tanang Bukit Sileh dan Nagari Kampung Batu Dalam Kabupaten Solok. Alasannya karena sebagian besar masyarakat yang ada di nagari-nagari tersebut menolak terhadap rencana pembangunan PLTP dibahu Gunung Talang dan nagari-nagari tersebut masih aktif melakukan penelokan tersebut sampai saat ini.Pemilihan informan dalam penelitian ini menggunakan teknik purposive sampling. Alasan peneliti mengunakan teknik ini karena peneliti sudah memiliki pemetaan terhadap orang yang akan dijadikan informan. Informan dalam penelitian ini adalah masyarakat yang tergabung ke dalam Aliasi Masyarakat Salingka Gunung Talang yang kontra terhadap renacana pembangunan PLTPdi Gunung Talang. Kemudian informan lainnya adalah beberapa Walinagari/ perangkatnya (Batu Bajanjang, Selayo Tanang Bukit Sileh dan Kampung Batu Dalam), serta tokoh masyarakat.

Metode pengumpulan data yang dilakukan dalam penelitian ini adalah observasi, wawancara mendalam dan dokumentasi (Sugiyono, 2016). Dalam menguji keabsahan data, penulis melakukan triangulansi pengamat dari Neuman dengan menggunakan beberapa informan untuk melengkapi keterbatasan informasi dari informan tunggal, sehingga informasi yang didapatkan dalam wawancara lebih mendalam dan dapat menjawab semua pertanyaan peneliti mengenai resistensi masyarakat terhadap rencana pembangunan PLTP di Gunung Talang. Data dianggap valid apabila jawaban dari informan sudah menunjukkan hal yang sama, sehingga tidak ada lagi perbedaan informasi dari hasil wawancara.

Analisis data merupakan suatu penyusunan data agar data tersebut dapat di tafsirkan. Menyusun data berarti mengelompokkan dalam pola atau kategori sedang tafsiran atau interpretasi artinya memberikan makna pada analisa dalam menjelaskan pola atau kategori dalam mencari dan mencari hubungan antar berbagai konsep (W.Creswell, 2016). Reduksi data merupakan proses pemilihan, pemusatan perhatian pada penyederhanaan, pengabstrakan dan transformasi data kasar yang muncul di lapangan. Pengabstrakan yang dimaksud dalam penelitian ini adalah membuat rangkuman (menajamkan, menggolongkan, mengarahkan serta membuang yang tidak perlu) proses penelitianmengenai sikap resistensi masyarakatterhadap rencana pembangunan PLTP di Gunung Talang.Penyajian-penyajian data dalam penelitian ini dapat menggunakan bagan ataupun kumpulan-kumpulan kalimat. Penyajian data atau display data merupakan penyajian data secara sederhana yang dapat mempermudah dalam penarikan kesimpulan. Penyajian data ini di perlukan supaya agar tidak menyimpang dari pokok permasalahan.Verifikasi dalam penelitian ini dilakukan secara kontinu selama peneliti melakukan penelitian dengan tujuan menganalisis dan mencari makna dari informasi yang di kumpulkan. Penarikan kesimpulan dilakukan untuk mengumpulkan data-data hasil wawancara dan observasi mengenai alasan resistensi masyarakat yang menolak rencana pembangunan PLTP atau geothermal di Gunung Talang.

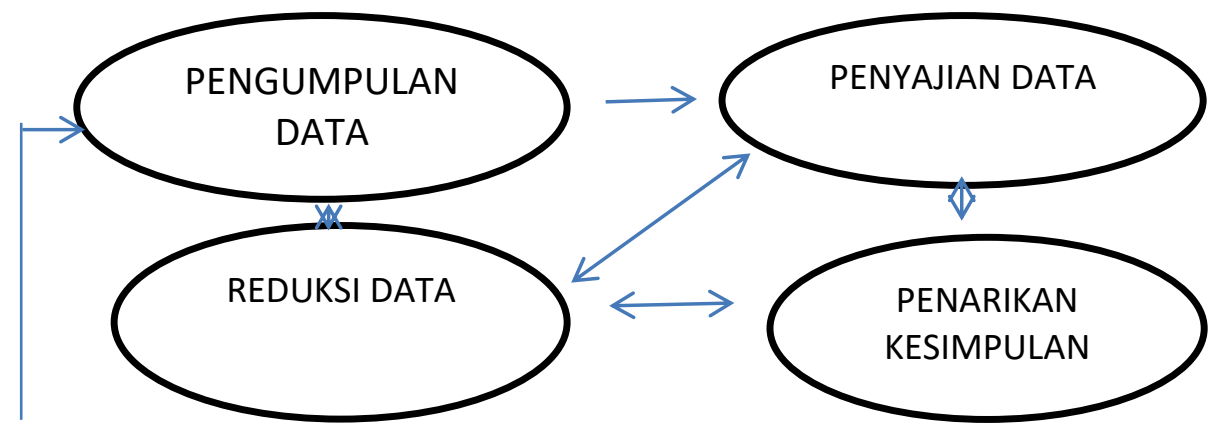

Gambar 1. Analisa Data Menurut Miles Dan Huberman

Jurnal Perspektif: Jurnal Kajian Sosiologi dan Pendidikan Vol. 2, No. 3, Th. 2019 


\section{Hasil dan Pembahasan}

Inovasi merupakan suatu pembaharuan terhadap berbagai sumber daya sehingga sumber daya tersebut mempunyai manfaat yang lebih bagi manusia. Proses inovasi sangat dipengaruhi oleh kemajuan teknologi dan ilmu pengetahuan karena kedua hal tersebut dapat memudahkan dalam memproduksi sesuatu memproduksi sesuatu yang baru dan berbeda. Proses inovasi ini akan terjadi secara terus-menerus di dalam kehidupan manusia karena adanya keinginan untuk melakukan sesuatu menjadi lebih mudah dan cepat.

Suatu inovasi akan diterima oleh masyarakat apabila inovasi tersebut menguntungkan, sesuai dengan nilai-nilai yang terdapat pada masyarakat yang bersangkutan, tidak rumit dan dapat dicobakan serta dapat dilihat. Salah satu satu contoh inovasi tersebut adalah Pembangkit Listrik Tenaga Panas Bumi (PLTP) yang memanfaatkan jasa lingkungan yaitu panas bumi atau geothermal. Pembangkit Listrik Tenaga Panas Bumi akan dibangun di Gunung Talang Kabupaten Solok, tetapi pembangunan ini mendapat penolakan dari masyarakat di sekitar Gunung Talang dan menunjukkan sikap resisten. Resistensi merupakan sikap yang menunjukkan untuk berperilaku bertahan, berusaha menentang dan melakukan perlawanan secara terang-terangan ataupun diam-diam atas suatu kebijakan yang dilakukan oleh sekelompok orang atau suatu kelompok masyarakat.

Penolakan masyarakat terhadap rencana pembangunan geothermal ini disebabkan karena tiga alasan yang melatarbelakangi, yaitu sebagai berikut:

Pertama, faktor pengetahuan. Pengetahuan didefenisiskan sebagai kapasiti untuk memperoleh, mengekal, dan menggunakan maklumat; campran kefahaman, pengalaman, kearifan dan kemahiran (A \& M, 2015). Pengetahuan adalah suatu istilah yang digunakan untuk menuturkan apabila seseorang mengenal tentang sesuatu. Sesuatu yang menjadi pengetahuan adalah unsusr-unsur yang mengetahui dan diketahui serta kesadaran mengenai hal yang ingin diketahui. Pengetahuan merupakan hasil usaha manusia untuk memahami suatu objek tertentu. Sejalan dengan proses penciptaan difusi dari Everett M. Rogers bahwa mempelajari inovasi merupakan tahap paling awal masyarakat melihat dan mengenali inovasi baru dari barbagai sumber (Saputra, 2018). Suatu inovasi akan diadopsi dengan cepat apabila inovasi tersebut mudah diaplikasikan, sebaliknya inovasi tidak akan diadopsi apabila inovasi tersebut sulit dimengerti dan diaplikasikan. Dalam tahap ini, seseorang belum memiliki informasi mengenai inovasi baru. Oleh karena itu, informasi mengenai inovasi tersebut harus disampaikan melalui berbagai saluran komunikasi yang ada. Melalui saluran-saluran komunikasilah terjadi pengenalan, pemahaman dan penilaian yang kelak akan menghasilkan penerimaan ataupun penolakan terhadap suatu inovasi.

Pengetahuan masyarakat terhadap geothermal yang akan dibangun di Gunung Talang belumlah lengkap, karena masyarakat menyamakan geothermal ini dengan pertambanganpertambangan migas yang ada di Indonesia dan pengetahuan itu hanya sekedar pemahaman terhadap dampak yang akan timbul akibat dari kecelakaan kerja yang mungkin terjadi jika pembangunan ini dilanjutkan. Tidak ada dari masyarakat maupun elit desa yang memiliki pengetahuan mendalam terhadap geothermal. Bagaimana pembangunan geothermal dan tujuan pembangunan itu dilakukan masyarakatpun juga tidak tahu. Rendahnya pengetahuan masyarakat terhadap geothermal dipengaruhi oleh beberapa aspek.

Pertama, kurangnya sosialisasi yang dilakukan oleh pihak PT. Hitay Daya Energi dan Pemerintah, sehingga berujung penolakan terhadap rencana pembangunan proyek geothermal di Gunung Talang. Pada tahun2016, PT. Hitay Daya Energi beserta elit desa sudah melakukan kunjungan ke mushala-mushala yang tersebar di Nagari Batu Bajanjang. Dalam kunjungan itu PT. Hitay Daya Energi dan elit desa hanya memberi tahu kepada masyarakat, bahwa akan ada pembangunan proyek geothermal di Gunung Talang, tetapi tidak dijelaskan secara rinci kepada masyarakat karena pada saat itu juga bertepatan dengan bulan Ramadhan. 
Dimana mushala-mushala tersebut juga sedang ada kegiatan tahunan, jadi waktu kunjungan tersebut terbatas dan membuat pesan pembangunan itu tidak tersampaikan dengan baik. Apalagi dalam kunjungan tersebut hanya sebagian kecil dari masyarakat yang hadir dan kunjungan itu hanya dilakukan disatu nagari saja.

Dalam rencana pembangunan ini seharusnya sosialisasi harus digencarkan kepada masyarakat sesuai dengan keadaan masyarakat yang berada disekitar lokasi pembangunan tersebut agar tercipta sinkronisasi antara harapan dan realitas pada masyarakat. Seharusnya pemerintahlah yang menjadi saluran komunikasi yang akan menyampaikan pesan pembangunan ini kepada masyarakat dan menjadi pusat informasi, tetapi proses ini tidak terlihat dalam rencana pembangunan proyek geothermal di Gunung Talang. Masyarakat disekitar Gunung Talang hanya memperoleh informasi dari mulut ke mulut antar mereka yang tidak diketahui apakah benar atau tidaknya informasi tersebut, karena tidak adanya sumber informasi atau saluran komunikasi yang dapat menjawab ketidaktahuan masyarakat akan pembangunan geothermal. Ketika tidak adanya sumber informasi dari pemerintahan, masyarakat mencari sumber informasi yang lain, yaitu LBH (Lembaga Bantuan Hukum) Padang. Selain sebagai sumber informasi, LBH juga merupakan perpanjangan tangan masyarakat dalam menolak rencana pembangunan proyek geothermal di Gunung Talang. Masyarakat yakin dan percaya bahwa LBH dapat membantu mereka dalam mengkritisi kebijakan pemerintah dalam pembangunan ini, karena selama ini LBH selalu memperjuangan hak-hak masyarakat sipil yang didominasi oleh negara pemerintah. Beberapa tahun belakangan ini, meski tema pokoknya tetap sama, akan tetapi, isu lebih menukik pada kasus atau persoalan lokal, misalnya kesewenang-wenangan oknum pemerintahan ditingkat lokal, kerusakan lingkungan yang diakibatkan oleh kebijakan pemerintahan daerah, korupsi di lingkungan dinas instansi tertentu, kemiskinan struktural yang terjadi di daerah dan seterusnya (Amri, Putra, \& Fernandes, 2016). LBH aktif membantu masyarakat sejak awal terjadi penolakan. Contoh kegiatan yang diselenggarakan oleh LBH dalam penolakan terhadap proyek geothermal adalah Camp us Talang pada tanggal 26-28 april 2019yang bertempat di Batu Tembak, Kenagarian Salayo Tanang Bukit Sileh. Kemudian, bedah film sexi killer dilabor Sosiologi FIS UNP pada bulan april 2019. Dalam acara bedah film tersebut juga sedikit membahas permasalahan geothermal yang akan dibangun di Gunung Talang.

Kedua, minimnya partisipasi masyarakat. Kurangya pelibatan masyarakat terhadap rencana pembangunan proyek geothermal juga mengakibatkan penolakan yang beresiko terhadap munculnya konflik antara PT. Hitay Daya Energy dan masyarakat sekitar Gunung Talang. Dalam hal ini, geothermal merupakan suatu bentuk inovasi yang tidak berhubungan langsung dengan masyarakat setempat, tetapi membutuhkan dukungan dari masyarakat yang bersangkutan. Seharusnya sesuai dengan prinsip Free Prior Informed Consent (FPIC), bahwa masyarakat harus diutamakan, didengar dan diberi informasi menyeluruh terhadap dampak lingkungan yang muncul dari eksploitasi sumber energi di Gunung Talang tersebut.

Ketiga, rendahnya tingkat pendidikan masyarakat. Pendidikan merupakan sebuah proses untuk memanusiakan manusia menuju kualitas hidup menjadi lebih baik. Jika tingkat pendidikan tersebut masih rendah, maka akan menghasilkan permasalahan-permasalahan sosial pada masyarakat. Pendidikan mempengaruhi proses belajar, makin tinggi pendidikan seeorang makin mudah orang tersebut untuk menerima informasi(Ii \& Sistem, 2001). Hal ini dapat dilihat pada masyarakat Nagari Batu Bajanjang, Nagari Salayo Tanang Bukit Sileh dan Nagari Kampung Batu Dalam yang sebagian besar masyarakatnya hanya tamat Sekolah Dasar. Rendahnya tingkat pendidikan masyarakat membuat mereka tidak mampu untuk berpikir kritis dan tidak memiliki wawasan yang luas. Sebagaimana pengetahuan mereka terhadap geothermal yang akan dibangun di Gunung Talang, masyarakat beranggapan bahwa proyek geothermal hanya sebatas perusak lingkungan dan bencana bagi mereka.

Jurnal Perspektif: Jurnal Kajian Sosiologi dan Pendidikan Vol. 2, No. 3, Th. 2019 ISSN. 2622-174 
Kedua, faktor ekonomi. Ekonomi adalah cara atau suatu usaha yang dilakukan oleh masyarakat dalam mengatur perekonomian rumah tangga untuk menjadi lebih baik dengan tujuan dapat memenuhi kebutuhan hidup (Drerup, 2015). Salah satu motif ekonomi adalah pemenuhan kebutuhan sehari-hari yang berkaitan dengan mata pencaharian. Masyarakat yang berada disekitar Gunung Talang pada umumnya memiliki mata pecaharian sebagai petani. Mereka memanfaatkan tanah dan sumber air dari Gunung Talang sebagai irgasi lahan pertanian mereka.

Sesuai dengan penciptaan difusi menurut Everett M. Rogers tahap kedua adalah pengadopsian yang merupakan tahap warga mulai menggunakan inovasi yang sudah dipelajari (Hanafi, 1989). Diadopsi atau tidaknya suatu inovasi di pengaruhi oleh beberapa faktor, diantaranya adalah pertimbangan keuntungan yang akan diperoleh dan kemampuan yang dimiliki oleh seseorang. Sesorang atau kelompok masyarakat akan mengukur keuntungan yang akan didapatkan jika mengadopsi inovasi tersebut secara personal. Kemudian, melalui evaluasi dan diskusi dengan orang lain, dia mulai cenderung untuk mengadopsi atau menolak suatu inovasi.

Dalam pembangunan geothermal, tentu akan membawa dampak positif. Seperti: perbaikan akses jalan ke titik pembangunan, membuka lapangan pekerjaan, pemenuhan kebutuhan listrik dan lain sebagainya. Tetapi, manfaat ini tidak dirasakan langsung oleh masyarakat, karena manfaat ini tidak berhubungan dengan kebutuhan mereka. Masyarakat memperhitungkan keuntungan dan kerugian yang akan diperoleh kalau proyek pembangunan PLTP ini tetap berlanjut. Dalam perhitungan tersebut, kerugian yang diakibatkan lebih besar dibandingkan manfaat yang didapat, karena masyarakat beranggapan pembangunan ini nantinya akan berdampak pada berkurangnya tingkat kesuburan tanah dan tentu akan mempengaruhi hasil panen mereka. Apalagi kerusakaan yang ditimbulkan oleh pembangunan PLTP tersebut besar, mereka takut jika kehilangan pekerjaan karena lahan yang biasa digunakan masyarakat untuk bertani tidak layak lagi untuk ditanami sayur-sayuran.

Gunung Talang merupakan sebagai kawasan hulu Daerah Tangkapan Air yang menyuplai ketersediaan air untuk kawasan yang ada disekitarnya. Gunung Talang juga merupakan sebagai Kawasan Hutan Lindung yang berfungsi sebagai perlindungan sistem penyangga kehidupan untuk mengatur tata air, mencegah banjir, mengendalikan erosi dan memelihara kesuburan tanah. Masyarakat bersikap resisten karena takut sumber air yang mereka pergunakan untuk kehidupan sehari-hari tidak dapat lagi dinikmati. Selain itu, masyarakat disekitar kawasan Gunung Talang juga menggunakan sumber air tersebut sebagai irigasi lahan pertanian.

Perencanaan pembangunan proyek geothermal di Gunung Talang tidak sepenuhnya ditolak oleh masyarakat, adapula sebagian masyarakat yang mempelajari lalu menerima rencana pembangunan ini. Hal karena keuntungan yang didapatkan oleh masyarakat, seperti halnya pembukaan akses jalan baru dari Tabek Lanyek Nagari Batu Bajanjang menuju daerah Pusat Pemerintahan Kabupaten Solok di Arosuka. Akan tetapi, masyarakat yang menerima pembangunan ini belum sampai pada tahap pengembangan jaringan sosial atau menyebarluaskan ke lingkungan sekitarnya seperti apa yang diterangkan oleh Everett M. Rogers di dalam teorinya. Hal ini disebabkan karena masyarakat yang menerima rencana pembangunan proyek geothermal juga masih memiliki keterbatasan informasi terhadap dampak geothermal itu sendiri. Kurangnya informasi dan pemahaman terhadap masyarakat yang sudah mulai menerima inovasi juga di akibatkan karena kurangnya sumber informasi yang dapat menjawab keraguan mereka terhadap inovasi tersebut.

Ketiga, faktor sosial budaya. Faktor sosial merupakan suatu tatanan dalam banyak hubungan dengan posisi sosial tertentu yang berdasarkan pada sistem nilai dan norma yang berlaku dalam suatu kelompok masyarakat. Salah satu faktor sosial ini adalah suku bangsa,

Jurnal Perspektif: Jurnal Kajian Sosiologi dan Pendidikan Vol. 2, No. 3, Th. 2019 ISSN. 2622-174 
dimana masyarakat sekitar Gunung Talang mempunyai suku bangsa Minangkabau. Masyarakat disekitar Gunung Talang masih menganut dan memegang teguh nilai dan norma yang selama ini diwariskan secara turun temurun, yaitu kepemilikan yang dimiliki secara bersama atau kaum. Jadi tanah ini tidak boleh diperjual-belikan atau dimiliki secara pribadi. Budaya sangat erat hubungannya dengan masyarakat. Segala sesuatu yang terdapat dalam masyarakat ditentukan oleh kebudayaan yang dimiliki oleh masyarakat itu sendiri (Dr. Drs. H.M. Ali Syamsuddin A, S.Ag., 2010). Dalam hal ini, sesuai dengan teori Everett M. Rogers bahwa ada faktor-faktor lain yang akan mempengaruhi seseorang mengadopsi suatu inovasi adalah motivasi dari dalam diri, status sosial, nilai yang dianut, serta persepsi diri terhadap inovasi.

Tanah ulayat pada sebagian besar masyarakat Minangkabau hanya boleh digadaikan pada keadaan-keadaan tertentu, yaitu (1) gadih gadang indak balaki (perawan tua yang tak bersuami), (2) mayik tabujua di ateh rumah (mayat terbujur di atas rumah), (3) rumah gadang katirisan (rumah besar bocor/ rusak), dan (4) mambangkik batang tarandam (membongkar kayu yang terendam). Pada masyarakat Minangkabau, tanah merupakan suatu simbol yang sangat penting sebagai institusi adat matrilineal (garis keturunan menurut ibu) yang selama ini dipegang teguh oleh masyarakatnya.Dalam hal ini, masyarakat tetap menjunjung aturan-aturan adat bahwa tanah ulayat yang kepemilikannya secara bersama harus tetap dipertahankan dan wariskan ke anak kemenakan sesuai dengan ketentuan adat yang selama ini telah dianut oleh masyarakat Minangkabau.

Setiap daerah tidak akan terlepas dari penggunaan lahan yang bersifat dinamis yang dipengaruhi oleh berbagai faktor. Salah satunya adalah untuk memenuhi kebutuhan penduduk yang terus meningkat. Dengan adanya peningkatan jumlah penduduk dapat menyebabkan semakin meningkatnya pembangunan, khususnya pembangunan di bidang pemukiman (Andini, 2018). Namun dalam perubahan penggunaan lahan juga sering kali menuai penolakan dari masyarakat sekitar. Seperti halnya penolakan masyarakat sekitar Gunung Talang dalam pembebasan lahan untuk rencana pembangunan PLTP yang berpusat di Jorong Lurah Nagari Batu Bajajanjang Kecamatan Lembang Jaya Kabupaten Solok.Rencana pembangunanPLTPdi Gunung Talang merupakan proyek dengan skala nasional dengan luas 27.000 hektare termasuk tanah beberapa orang masyarakat di dalamnya. Pihak PT. Hitay Daya Energi dan pemerintah sudah menawarkan solusi dengan mengganti kerugian masyarakat terhadap penggunaan lahan untuk rencana pembangunan PLTP, tapi masyarakat tetap ingin mempertahankan lahan tersebut.Masyarakat tetap mempertahankan tanah tersebut karena selama ini mereka telah menggantungkan hidup pada tanah tersebut.

Dalam penolakan terhadap rencana pembangunan proyek geothermal sudah sampai pada tahap konflik dan perusakan, yaitu pembakaran satu unit mobil milik PT. Hitay Daya Energy pada tanggal 20 november 2017 lalu. Kejadiaan ini terjadi ketika pihak PT. Hitay Daya Energy hendak melakukan survei dititik pengeboran panas bumi di Jorong Lurah Nagari Batu Bajanjang. Atas insiden ini membuat tiga orang masyarakat ditetapkan menjadi tersangka pembakaran mobil dan dikenakan kurungan penjara oleh kepolisian. Tidak hanya konflik dengan PT. Hitay Daya Energi, rencana pembangunan proyekk geothermal juga membuat masyarakat terbelah menjadi dua, yaitu kelompok pro dan kelompok kontra. Keadaan masyarakat yang terbagi menjadi dua juga mengakibatkan munculnya konflikkonflik kecil yang non-realistis.

\section{Penutup}

Rencana pembangunan PLTP (Pembangkit Listrik Tenaga Panas Bumi)mendapat penolakan dari masyarakat yang bermukim di sekitar Gunung Talang. Berdasarkan hasil

Jurnal Perspektif: Jurnal Kajian Sosiologi dan Pendidikan Vol. 2, No. 3, Th. 2019 ISSN. 2622-174 
penelitian ini menunjukkan bahwa resistensi Masyarakat Salingka Gunuang Talang terhadap rencana pembangunan PLTP atau proyek geothermal disebabkan oleh beberapa hal, antara lain sebagai berikut. Pertama, Pengetahuan pengetahuan masyarakat terhadap inovasi geothermal masih minim, karena baranggapan bahwa geothermal sama dengan pertambangan migas dan pemahaman tersebut hanya sampai pada dampak yang akan ditimbulkan dari pembangunan tersebut. Kurangnya pengetahuan dan pemahaman masyarakat akan geothermal ini disebabkan karena (1) kurangnya sosialisasi, (2) minimnya partisipasi masyarakat dan (3) rendahnya tingkat pendidikan masyarakat. Kedua, masyarakat menolak juga dikarenakan tidak adanya keuntungan yang dirasakan secara langsung dari rencana pembangunan ini. Masyarakat merasa malah dirugikan, karena akan merusak kesuburan tanah dan tata kelola air. Sehingga, kerusakan ini akan berdampak pada berkurangnya hasil panen dan bahkan kehilangan pekerjaan sebagai petani karena lahan tersebut tidak layak lagi untuk di tanami sayur-sayuran.Ketiga, adanya beberapa orang masyarakat yang menolak karena permasalahan lahan atau tanah, baik itu tanah perorangan ataupun tanah ulayat.

\section{Daftar Pustaka}

A, J. H., \& M, H. (2015). Tradução não oficial da Recomendação da UNESCO, realizada pelo Instituto Brasileiro de Museus e revista pelo ICOM Portugal. 81(3), 103-115. https://doi.org/10.5194/nhess-9-289-2009

Afriandi, A., \& Hantoro, R. (2018). Analisis Pemanfaatan Geothermal Brine untuk Pembangkitan Listrik dengan Heat Exchanger. Jurnal Teknik ITS, 7(1). https://doi.org/10.12962/j23373539.v7i1.27687

Amri, E., Putra, E. V., \& Fernandes, R. (2016). Pola Hubungan Negara dan Civil Society. POLITIK, 12(2), 1821-1828.

Andini, N. F. (2018). Perubahan Penggunaan Lahan Kecamatan Gunung. 1(1), 19-25.

Dr. Drs. H.M. Ali Syamsuddin A, S.Ag., Ms. (2010). Sistem Sosial Budaya Indonesia. To

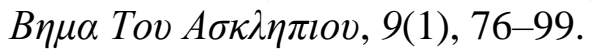

Drerup, M. M. (2015). Peningkatan Perekonomian Masyarakat Melalui Indutri Kecil. Skripsi. UIN Sunan Kalijaga

Hanafi, A. (1989). Memasyarakatkan Ide-ide Baru. Surabaya: Usaha Nasional.

Ii, B.B., \& Sistem, a P. (2001). Universitas Sumatera Utara 7. 7-37.

Kurniawan, A. H. (2013). Persistensi Dan Resistensi Masyarakat Terhadap Eksistensi Pertambangan Emas Di Desa Bonto Katute Kabupaten Sinjai.

Novenanto, P. A., \& Novenanto, A. (2016). Membangun Bencana: Tinjauan Kritis atas Peran Negara dalam Kasus Lapindo 1. 20(80), 159-192.

Rachmawan, P. D. (2016). Pola Eskalasi Konflik Pembangunan Infrastruktur : Studi Kasus Pembangunan Waduk. 20(80), 193-211.

Saputra, H. (2018). Rejection Penggunaan ATBM Dan ATBMTT Dalam Pembuatan Songket Pandai Sikek. SOCIUS, 5(1). https://doi.org/10.24036/socius/vol5-iss1/109

Sugiyono. (2016). Metode penelitian kombinasi. Bandung: Alfabeta.

Undang-Undang Republik Indonesia Nomor 21 Tahun 2014 Tentang Panas Bumi. (2014). 140.

W.Creswell, J. (2016). Research Design, Pendekatan metode Kualitatif, Kuantitatif dan campuran. Yogyakarta: Pustaka Belajar. 